\title{
Contrast Sensitivity and Color Vision as Biomarkers of the Preclinical Stage of Neurodegeneration in Huntington's Disease
}

\author{
DOI: 10.17691/stm2019.11.2.11
}

Received April 9, 2018

\section{S.N. Svetozarskiy, PhD Student, Department of Eye Diseases}

Privolzhsky Research Medical University, 10/1 Minin and Pozharsky Square, Nizhny Novgorod, 603005, Russia

The aim of the study was to investigate contrast sensitivity (CS) and color vision in Huntington's disease (HD), their correlation with clinical and genetic data, and the possibility of using the ophthalmological parameters as biomarkers of preclinical stage of neurodegeneration.

Materials and Methods. Participants in the study were divided into two groups, which included 44 HD subjects (main group) and 31 apparently healthy volunteers (control). In the main group, 21 subjects had pre-manifest and 23 manifest HD stage. The groups were age-, sex-, intraocular pressure-, and mean refractive error-matched. CAG (cytosine-adenine-guanine) repeat expansion size in the huntingtin gene, disease duration, and a motor function score according to the UHDRS were evaluated in HD patients. All patients underwent a thorough neurological and ophthalmic examination including CS evaluation using Freiburg Vision Test (FrACT), color vision assessment using Rabkin plates, and computer-assisted campimetry based on ApWay.ru Web platform.

Results. The range of the CAG repeat expansion size in the main group was $37-56$ repeats $(44.3 \pm 3.8)$, the UHDRS motor score 36.3 \pm 29.7 , disease duration $13.7 \pm 7.2$ years. CS in HD was reduced, there was a significant difference between the pre-manifest and manifest patients. The CS log inversely correlated with CAG repeat expansion size $(r=-0.627 ; p=0.001)$. When reading Rabkin plates, $\mathrm{HD}$ patients made significantly more nonspecific mistakes than controls. Color differentiation thresholds in the HD group were higher than in the control group in red, green and blue colors. During computer-assisted campimetry, the manifest HD patients made significantly more mistakes in the stimulus shape differentiation giving oral answers than choosing on the screen. Color differentiation thresholds in green $(r=0.489 ; p=0.003)$ and blue $(r=0.416 ; p=0.014)$ correlated with the UHDRS score. When plotting ROC curves, the differentiation threshold for blue color had been established to have the best diagnostic value for distinguishing between the control and pre-manifest HD patients.

Conclusion. The study results indicate visual sensory deprivation in HD. Color vision disturbances develop early at the pre-manifest $\mathrm{HD}$ stage, ahead of the CS decrease signifying early damage to the parvocellular vision pathway. Amnestic aphasia in the manifest HD patients makes it difficult to obtain correct oral answers during visual function evaluation. Color differentiation thresholds proved to be a promising biomarker for early diagnosis of neurodegenerative processes.

Key words: contrast sensitivity; color vision; Huntington's disease; neurodegeneration.

\section{Introduction}

Huntington's disease (HD) is a steadily progressive neurodegenerative disease with an autosomal dominant mechanism of inheritance caused by mutation in the huntingtin $(H T T)$ gene [1]. The prevalence of HD in the Caucasian race is $3.0-13.7$ per 100,000 people [2-5]. Mutation in the huntingtin gene is presented by the increase of cytosine-adenine-guanine (CAG) repeats [6], with the disease developing in $100 \%$ of carriers when the number of repeats exceeds 39 .

Two stages are distinguished in HD: pre-manifest and manifest [7-8]. The appearance of the typical motor symptoms is considered manifestation, the patient age at the time of manifestation being correlated with the number of $C A G$ repeats [8]. The median of survival after the debut of the motor symptoms is 18 years [9].

A monogenic inheritance, high penetrance, and exceptional opportunity of following-up patients at the asymptomatic stage allow HD to be considered as a "model" disease for studying early stages of the development of sporadic neurodegenerative diseases such as Alzheimer's and Parkinson's diseases [10].

Damage to the central and peripheral parts of the visual analyzer and associated visual dysfunction is typical for various hereditary and sporadic neurodegenerative diseases [11-13]. In HD, decrease of the white and grey matter volume in the brain occipital 
lobe (according to the magnetic resonance imaging data); amplitude reduction of the visual evoked brain potentials [14]; diminishing of the choroid thickness and a layer of the retinal nerve fibers (according to the optical coherence tomography) [15-17]; accumulation of huntingtin in the layers of the retina (in the experiment) [18] are noted. Single works are devoted to sensory visual functions where visuospatial disorders [19] and contrast sensitivity (CS) reduction in manifest HD are considered [20]. The analysis of color vision using quantitative methods has not been performed.

The aim of the investigation was to study the contrast sensitivity and color vision in patients with Huntington's disease, their correlation with clinical and genetic characteristics, and the possibility of using the ophthalmological parameters as biomarkers of the early stage of the neurodegenerative process and indicators of disease severity.

\section{Materials and Methods}

The participants of the investigation were divided into the main and control (conventionally healthy people and volunteers) groups. The criterion of inclusion into the main group was molecular genetic confirmation of Huntington's disease. Subjects with HD were at the pre-manifest and manifest stages of the disease. The criterion of inclusion into the control group was absence of significant ophthalmological and neurological pathology and known hereditary illnesses found by family history-taking.

The common criterion of exclusion in both groups included traumatic brain injury, cerebral circulation disorders, diabetes mellitus, hypertonic disease, ischemic heart disease, and other systemic illnesses with visual organ damage in the history. Patients with focal brain pathology found by computed tomography or magnetic resonance tomography were also excluded from the study.

The study complied with the declaration of Helsinki and was performed followed the approval by the Ethics Committee of Privolzhsky Research Medical University. Written informed consent was obtained from all the participants before the beginning of the study.

Genetic and neurological examination. All patients of the main group were tested for mutation in the HTT gene and identification of CAG repeats in this gene (Molecular Genetic Center, Moscow). The neurological examination included taking life and disease history, hereditary history, pedigree formation, clinical examination of the nervous system. Motor disorders were evaluated using the Unified Huntington's Disease Rating Scale (UHDRS), disease duration was determined from the time of manifestation.

The cognitive functions in the control group were assessed according to the Mini-Mental State Examination scale. The score less than 26 served as an exclusion criterion.
Ophthalmological examination. The basic examination in the main and control groups consisted of history-taking and objective investigation of both eyes including autorefractometry, visometry, tonometry, biomicroscopy, ophthalmoscopy, and the assessment of the vision character by means of the Worth's four dot test. Color vision was evaluated using Rabkin plates; depending on the number of unreadable plates three grades of dyschromatopsia were distinguished: light (1-9 plates), medium (10-15 plates), and severe (over 16 plates).

Excluded were patients with the best corrected vision acuity below 0.8 , ametropia and astigmatism of the medium and high severity degree, intraocular pressure over $22 \mathrm{~mm} \mathrm{Hg}$ (according to Maklakov), any significant medial opacity at the time of examination, diseases in the history and found on examination (primarily, glaucoma or suspected glaucoma), sequels of injuries and operative interventions on eyes.

Determination of color differentiation thresholds. All tests for CS and color vision in both groups were carried out before pupil dilation in one and the same room under photopic conditions with artificial illumination using a 17" LCD monitor at constant settings of lightness $(100 \%)$ and contrast (100\%).

Color differentiation thresholds were determined by a computer-assisted campimetry test based on ApWay.ru Web platform [21-24] under binocular conditions at a distance of $1 \mathrm{~m}$. The stimulus and background parameters were programmed in compliance with a color HSL model being the best for human color perception and intuitively clear [24, 25]. In the HSL model, color is determined by three parameters: a hue, saturation, and lightness. The saturation and lightness were set constant while a stimulus hue and shape were variables.

The stimulus represented a monochrome color spot in the form of a geometric figure (Figure 1), the stimulus and background hue were assigned in degrees according to the HSL model (Figure 2).

The study algorithm consisted of 11 tasks for stimulus searching. The first task served as an explanation, the second was trial, and further the tests were conducted in a random order for discrimination of different hues of the red $\left(350^{\circ}, 0^{\circ}, 10^{\circ}\right)$, green $\left(110^{\circ}, 120^{\circ}, 130^{\circ}\right)$, and blue $\left(230^{\circ}, 240^{\circ}, 250^{\circ}\right)$ colors. The participants

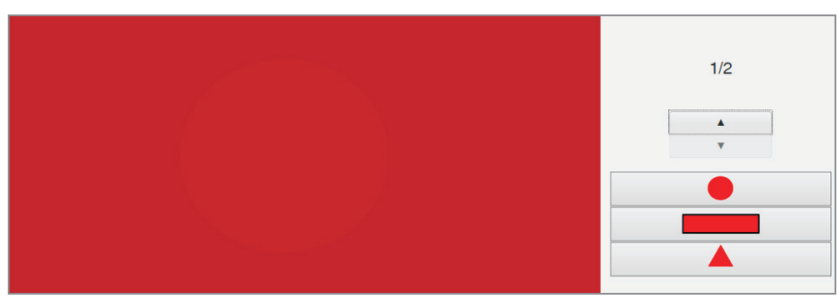

Figure 1. Example of the task for finding the stimulus during computer-assisted campimetry 


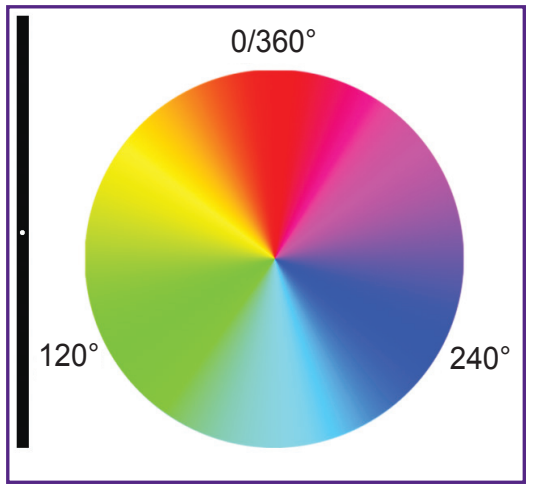

Figure 2. Conformity of color hues perceived by the eye (hue, $\mathrm{H} \in\left[0^{\circ}, 360^{\circ}\right]$ ) with their position in the color HSL model:

red $-0 / 360^{\circ}$; green $-120^{\circ}$; blue $-240^{\circ}$

were asked to define the shape of the color spot. At the beginning of the task, the hues of the background and spot were similar, the color was controlled by a patient who, by clicking the mouse button, changed the color by $1^{\circ}$ till he found the stimulus. When the stimulus is detected, the spot shape should be named verbally and the model figure shown with a mouse click or with a finger on the screen (in case of motor disorders) (see Figure 1). The number of mistakes made in determining the spot shape by clicking and naming was registered. The difference between the hue of the stimulus and background at which the patient defined the spot shape was considered a color differentiation threshold. During the analysis, the greatest value of the three color differentiation thresholds was used for the hues of red, green, and blue colors.

Measurements of contrast sensitivity. The CS was assessed using a freely distributable software Freiburg Vision Test (FrACT), 3.9.3 version, recognized to be informative and sensitive for CS examination in neurodegenerative diseases [26, 27]. According to the recommendations (http://michaelbach.de/fract/), the contrast of optotypes was set in the program settings at $100 \%$, the dark stimulus on the light background, the stimulus diameter at 50 angular minutes. The contrast $\left(C_{W}\right)$ was calculated by the program using Weber's formula $\left.\left(C_{W}=L b-L t\right) / L b\right)$, where contrast is the ratio of the difference of the object ( $\mathrm{Lt}$ ) and background $(\mathrm{Lb})$ lightness to the background lightness. The CS value is the inverse of the CS threshold. The CS threshold was automatically calculated by the program using best PEST (Best Parameter Estimation by Sequential Testing) [28] algorithm. The value of CS logarithm $\left(\log C S=\log \left(1 / C_{W}\right)\right)$ characterized by normal distribution was used for analysis. The examination was performed monocularly at the $1.5 \mathrm{~m}$ distance. The CS examination consisted in presenting on the screen a Landolt broken ring optotype with a constant diameter but different contrast relative to the background (Figure 3 ). The

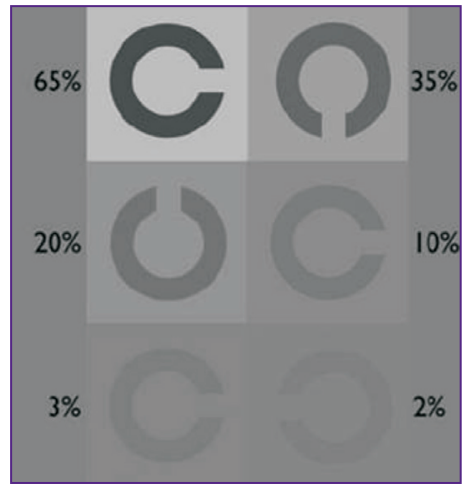

Figure 3. Images of Landolt broken rings of different contrast presented to the examined persons during testing Image contrast values are given according to Weber's contrast measure

examined patient was to show the direction of the ring gap by a key click (the protocol included 18 tests carried out after learning).

Statistical analysis was performed using the applied SPS 22.0 software package for Windows. Continuous variables were presented as $M \pm S D$, where $M$ is arithmetic mean, SD is standard deviation. The normality of distribution was tested using Shapiro-Wilk test. To compare two groups with normal distribution of the variable and equal dispersions, the Student's t-test was applied for independent samples, in other cases, the nonparametric Mann-Whitney U-test was used. To analyze the categorical variables (gender), $\chi^{2}$ criterion was employed. Relations between the parameters of visual functions and clinical and genetic characteristics were investigated using Pearson correlation coefficient (r) presenting statistically significant correlations the dependences with a notable binding force were depicted graphically (according to the Cheddok scale, $r>0.5)$

In order to assess the diagnostic value of the ophthalmological parameters for revealing pre-manifest $H D$, the characteristic ROC curves were plotted and the area under the curve (AUC) was calculated. A 5\% $(p<0.05)$ level of significance was accepted. When comparing the parameters for the right and left eyes of the patients and volunteers, the statistically significant difference was not found and the analysis was performed only on the basis of the right eye data for each patient.

\section{Results}

In compliance with the inclusion criterion, 47 participants of the main group and 31 volunteers of the control group were examined. In the course of examination, $3 \mathrm{HD}$ patients were excluded from the main group: two with radial keratotomy in the history and one with diabetes mellitus type 2 . In this connection, 
the data of 44 participants (44 eyes) of the main group ant 31 volunteers ( 31 eyes) from the control group were analyzed. In the main group, 21 participants had a premanifest stage of the disease, 23 - a manifest stage. The number of CAG repeats in the huntingtin gene varied from 37 to $56(44.3 \pm 3.8)$, the score in the manifest patients amounted to $36.3 \pm 29.7$ according to the motor UHDRS scale, disease duration was $13.7 \pm 7.2$ years. No statistically significant difference in age, gender distribution, vision acuity, and intraocular pressure level was found between the main and control groups (Table 1). However, there was revealed the difference in age $(p<0.001)$ between the manifest and premanifest patients which correlated with the successive development of the disease stages. The results of the Worth's four dot test showed that all examined participants had binocular vision.

During color sense examination using Rabkin plates, all participants from the main and control group read plates I and || correctly demonstrating a sufficient cognitive preservation in the examined patients. While reading the rest of the plates, patients with HD made more mistakes (Table 2), the number of which grew with the development of the manifest stage of the disease relative to pre- manifest. All examined participants were trichromats, part of the patients of the main group had abnormal trichromatism referred to dyschromatopsia of the light degree. In neither case could dyschromatopsia be classified as congenital abnormality of color perception.

The thresholds of color differentiation in the main group were higher than in the control in the hues of red, green, and blue colors (see Table 2). There were no statistically significant differences within the main group between the manifest and pre-manifest HD carriers, but at the same time, there was a tendency to the increase of color differentiation thresholds after clinical manifestation of HD.

The analysis of the number of mistakes in determining the stimulus shape showed that conventionally healthy volunteers and pre-manifest HD carriers did not make mistakes. Patients at the manifest stage made significantly more mistakes in oral answers than in choosing the spot shapes among those presented on the monitor screen $(p=0.045)$ (Figure 4).

The CS logarithm in HD was lower in the control group, and in the patients at the manifest stage of HD a significant attenuation of the CS function was noted compared to the pre-manifest stage.

Table 1

Description of the examined groups $(\mathrm{M} \pm \mathrm{SD})$

\begin{tabular}{lcccccc}
\hline \multicolumn{1}{|c}{ Parameters } & $\begin{array}{c}\text { Main group } \\
(\mathrm{n}=44)\end{array}$ & $\begin{array}{c}\text { Pre-manifest stage } \\
\text { of Huntington's } \\
\text { disease }(\mathrm{n}=21)\end{array}$ & $\begin{array}{c}\text { Manifest stage } \\
\text { of Huntington's } \\
\text { disease }(\mathrm{n}=23)\end{array}$ & $\begin{array}{c}\text { Control group } \\
(\mathrm{n}=31)\end{array}$ & $\begin{array}{c}\mathrm{p} \\
\text { (main vs. control) }\end{array}$ \\
\hline Age (years) & $37.6 \pm 10.2$ & $30.63 \pm 4.62$ & $42.60 \pm 10.20$ & $37.3 \pm 10.8$ & $0.900^{*}$ \\
\hline Men/women & $24 / 20$ & $7 / 14$ & $17 / 6$ & $15 / 16$ & $0.599^{*+}$ \\
\hline The best corrected vision acuity & $1.0 \pm 0.02$ & $1.0 \pm 0.0$ & $1.0 \pm 0.02$ & $1.01 \pm 0.09$ & $0.260^{*}$ \\
\hline Intraocular pressure (mm Hg) & $19.3 \pm 1.7$ & $18.9 \pm 1.4$ & $19.5 \pm 1.8$ & $19.3 \pm 1.5$ & $0.945^{*}$ \\
\hline Presence/absence of binocular vision & $44 / 0$ & $21 / 0$ & $23 / 0$ & $31 / 0$ & - \\
\hline
\end{tabular}

* Significance level $p$ for Student's t-test for independent samples; ${ }^{+}$significance level for $\chi^{2}$ criterion.

Table 2

Contrast sensitivity logarithm and color differentiation thresholds in subjects with Huntington's disease and in the control group (MISD)

\begin{tabular}{|c|c|c|c|c|c|c|}
\hline Parameters & $\begin{array}{l}\text { Main group } \\
\quad(n=44)\end{array}$ & $\begin{array}{l}\text { Pre-manifest stage } \\
\text { of Huntington's } \\
\text { disease }(n=21)\end{array}$ & $\begin{array}{l}\text { Manifest stage } \\
\text { of Huntington's } \\
\text { disease }(n=23)\end{array}$ & $\begin{array}{l}\text { Control } \\
\text { group }(n=31)\end{array}$ & $\begin{array}{c}p \\
\text { (main vs. } \\
\text { control) }\end{array}$ & $\begin{array}{c}p \\
\text { (pre-manifest vs. } \\
\text { manifest) }\end{array}$ \\
\hline Contrast sensitivity logarithm & $1.712 \pm 0.210$ & $1.785 \pm 0.166$ & $1.646 \pm 0.227$ & $2.005 \pm 0.141$ & $<0.001^{*}$ & $0.025^{+}$ \\
\hline $\begin{array}{l}\text { Number of mistakes when reading } \\
\text { Rabkin plates }\end{array}$ & $0.86 \pm 1.15$ & $0.429 \pm 0.676$ & $1.26 \pm 1.36$ & $0.194 \pm 0.477$ & $0.0031^{+}$ & $0.0293^{+}$ \\
\hline $\begin{array}{l}\text { Color differentiation threshold } \\
\text { for the hues of red }\left(^{\circ}\right)\end{array}$ & $8.36 \pm 1.95$ & $7.81 \pm 1.54$ & $8.87 \pm 2.18$ & $6.74 \pm 1.21$ & $<0.001^{*}$ & $0.068^{+}$ \\
\hline $\begin{array}{l}\text { Color differentiation threshold } \\
\text { for the hues of green }\left(^{\circ}\right)\end{array}$ & $12.02 \pm 4.57$ & $11.24 \pm 4.33$ & $12.74 \pm 4.75$ & $8.74 \pm 3.23$ & $0.001^{*}$ & $0.279^{+}$ \\
\hline $\begin{array}{l}\text { Color differentiation threshold } \\
\text { for the hues of blue }\left(^{\circ}\right)\end{array}$ & $7.77 \pm 2.46$ & $7.62 \pm 2.20$ & $7.91 \pm 2.71$ & $5.03 \pm 0.983$ & $<0.001^{*}$ & $0.694^{+}$ \\
\hline
\end{tabular}

* Significance level $p$ for Student's t-test for independent samples; ${ }^{+}$significance level $p$ for Mann-Whitney U-test. 


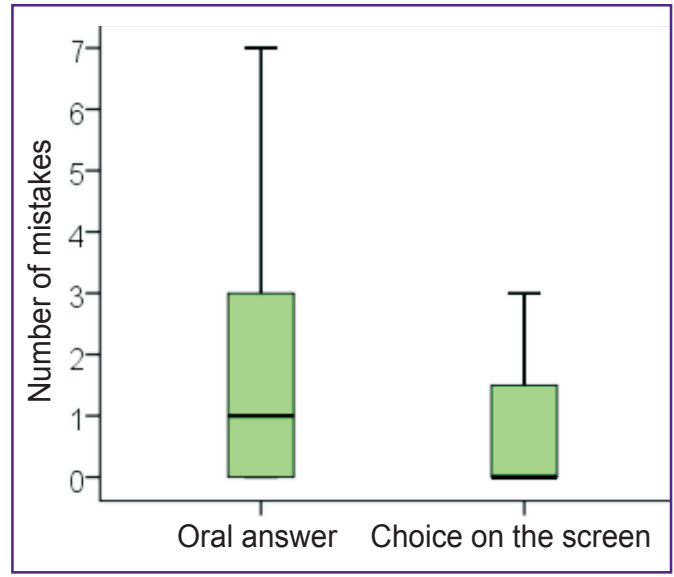

Figure 4. Investigations of color vision using computerassisted campimetry in patients at the manifest stage The diagram demonstrates the decrease in the number of mistakes in determining the stimulus shape on the monitor screen in comparison with the oral answers $(p=0.045)$

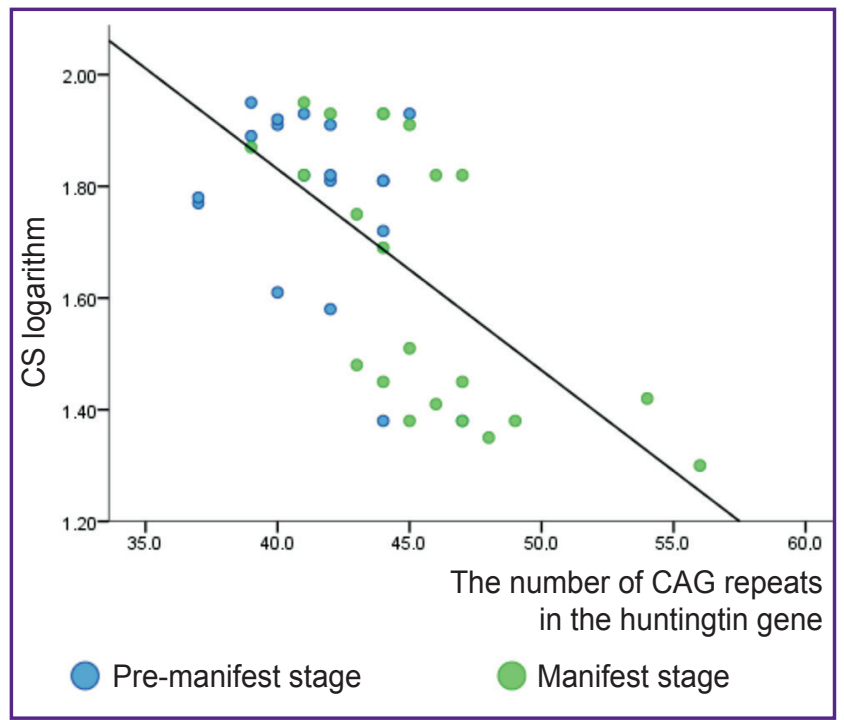

Figure 5. Negative correlation between the number of CAG repeats in the huntingtin gene and the contrast sensitivity logarithm in Huntington's disease

Pre-manifest HD carriers have higher values of the contrast sensitivity logarithm

The CS log was inversely related to the number of CAG repeats $(r=-0.627 ; p=0.001$; Figure 5). The thresholds of color differentiation in green $(r=0.489$; $p=0.003)$ and blue $(r=0.416 ; p=0.014)$ correlated with the score of the motor UHDRS scale.

The CS log was of low diagnostic value for revealing pre-manifest HD, whereas color differentiation thresholds showed higher area values under the ROC curve (Table 3). During the ROC curve building, the greatest diagnostic value was demonstrated by the threshold of blue color differentiation (Figure 6).
Table 3

The diagnostic value of the examined parameters in differentiating pre-manifest Huntington's disease from the control

\begin{tabular}{lcc}
\hline \multicolumn{1}{c}{ Parameters } & $\begin{array}{c}\text { Area } \\
\text { under the curve }\end{array}$ & $p$ \\
\hline $\begin{array}{l}\text { Contrast sensitivity logarithm } \\
\begin{array}{l}\text { Color differentiation threshold } \\
\text { for the hues of red }\end{array}\end{array}$ & 0.117 & $<0.001$ \\
\hline $\begin{array}{l}\text { Color differentiation threshold } \\
\text { for the hues of green }\end{array}$ & 0.642 & 0.085 \\
\hline $\begin{array}{l}\text { Color differentiation threshold } \\
\text { for the hues of blue }\end{array}$ & 0.716 & 0.009 \\
\hline
\end{tabular}

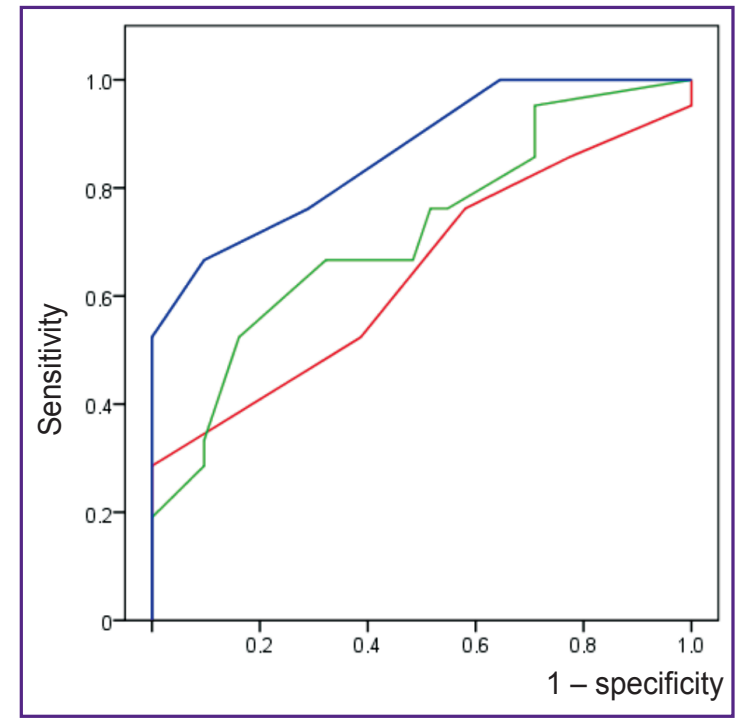

Figure 6. Color differentiation thresholds in the diagnosis of the pre-manifest Huntington disease using characteristic ROC curves

A threshold of color differentiation in the hues of blue color demonstrates the greatest diagnostic value

\section{Discussion}

Color vision disorders are known to be noted at the stage of a mild cognitive decline and to progress in Alzheimer's disease. The tests for color differentiation are considered as biomarkers of the early stage of this disease [29]. Values of color differentiation thresholds in Parkinson's disease correlate with a prominent motor dysfunction which is supposed to be associated with a common pathogenesis of motor and sensory disturbances [30]. Findings of our color vision investigations in $\mathrm{HD}$ demonstrate similarity with the described changes in Alzheimer's and Parkinson's diseases: impairment of color differentiation occurs already at the pre-manifest stage anticipating the development of characteristic motor disorders. Besides, at the manifest stage, there is a correlation between 
the sensory and motor disorders designating the concurrently running processes of neurodegeneration in various parts of the central nervous system.

Progression from a mild cognitive decline to Alzheimer's disease is accompanied by the reduction in CS [31-34] and retina thickness in the macular zone [33]. In Parkinson's disease, CS correlates with the severity of cognitive disturbances [35] and is accompanied by gaze fixation disorder [36] which allows this sign to be considered as a marker of the non-motor disorder severity in parkinsonism [36].

To explain the causes of CS reduction in HD, it should be noted that CS depends on optical factors as well as on functioning of the nerve cell networks. In terms of optics, CS is connected with a frequency-contrast characteristic of the eye as a lens determined primarily by the pupil diameter [37]. From the point of view of conduction pathway functioning, CS is mediated by numerous optic canals selective to various spatial frequencies [38]. When examining the carriers of the huntingtin gene, we did not detect any disorders of pupil reaction, the pupil width was evaluated as physiological in all cases. Thus, no gross abnormalities in the frequency-contrast characteristic of the vision organ were found.

Our results show that CS reduction is typical for the manifest stage of the disease and cannot be considered as a marker of the early HD stage. In contrast to the CS assessment with the help of sinusoidal gratings with different spatial frequency [20], examination of CS using optotypes showed the association of CS log with the number of CAG repeats in the huntingtin gene. The increase in the number of CAG repeats results in an earlier and heavier course of HD and mainly in motor and psychiatric disorders [1, 39, 40]. The data obtained by us point for the first time to the connection of the genetic characteristic of the patients with the severity of the visual dysfunction. A complex study and search for the links between the impairment of the visual and oculomotor functions together with the retina tomographic parameters are of great interest and demand further investigations.

Color vision disorder at the early stage of neurodegeneration, compared to CS, gives evidence in favor of the hypothesis advanced by La Morgia et al. [41] on mainly a paracellular or papillomacular pattern of neurodegeneration in $\mathrm{HD}$ especially at the pre-manifest stage. This succession is explained by the experimental data indicating earlier damage of the cones (than rods) by huntingtin deposits in HD progression [18].

During color vision tests it was established that naming an object artificially increases the number of mistakes. It is caused by amnestic aphasia at the manifest HD stage [38]. In this connection, for examining visual functions in patients with neurological deficit symptoms [42] advantageous are computer-assisted campimetry and contrastometry $[43,44]$ which exclude the necessity of oral answers thereby upgrading the validity of the study.

\section{Conclusion}

The data obtained allow us to speak about a phenomenon of visual sensory deprivation in Huntington's disease. The study findings showed for the first time that color vision disorders are developing already at the pre-manifest stage occurring before the reduction of contrast sensitivity which is observed at the manifest stage. Patients with Huntington's disease make more nonspecific mistakes when reading Rabkin plates and their number increases with the development of the manifest stage of the disease. The increase of color differentiation thresholds in the shades of red, green, and blue colors in Huntington's disease correlates with the severity of motor disorders according to the UHDRS. The color differentiation threshold in the hues of blue appeared to be the most promising biomarker of the premanifest stage.

For the first time, the relation between contrast sensitivity and the number of CAG repeats in the huntingtin gene has been detected. The reduction of contrast sensitivity in Huntington's disease occurs at the preserved visual acuity, progresses with the development of the manifest stage, and has inverse connection with the number of $C A G$ repeats in the huntingtin gene.

It is necessary to continue studying visual functions in Huntington's disease, their links with morphological changes of the retina and brain as well as the impact of the visual function on the patients' quality of life.

Acknowledgement. The author is sincerely grateful to I.G. Smetankin, MD, DSc, for the scientific editing of the paper, to S.V. Kopishinskaya, MD, PhD, for thorough neurological and genetic examination of the patients, to S.A. Polevaya, DSc, for the assistance in the work with ApWay.ru Web platform used to for color vision testing.

Study funding. The work was not supported by any financial source.

Conflicts of interest. The author has no conflicts of interest to disclose.

\section{References}

1. McColgan P., Tabrizi S. Huntington's disease: a clinical review. Eur J Neurol 2018; 25(1): 24-34, https://doi. org/10.1111/ene.13413.

2. Seliverstov Y., Dranitsyna M., Ivashynka A., Kravchenko M., Klyushnikov S., Illarioshkin S. Huntington disease in Russia: an epidemiological challenge? Neurology 2017; 88(Suppl 16): P4.323-P4.323.

3. Fisher E., Hayden M. Multisource ascertainment of Huntington disease in Canada: prevalence and population at risk. Mov Disord 2013; 29(1): 105-114, https://doi.org/10.1002/ mds. 25717 .

4. Morrison P.J., Harding-Lester S., Bradley A. Uptake of Huntington disease predictive testing in a complete population. Clin Genet 2010; 80(3): 281-286, https://doi.org/10.1111/ j.1399-0004.2010.01538.x.

5. Evans S., Douglas I., Rawlins M., Wexler N., Tabrizi S., Smeeth L. Prevalence of adult Huntington's disease in the 
UK based on diagnoses recorded in general practice records. J Neurol Neurosurg Psychiatry 2013; 84(10): 1156-1160, https://doi.org/10.1136/jnnp-2012-304636.

6. Ivanova-Smolenskaia I.A., Ovchinnikov I.V., Illarioshkin S.N., Markova E.D., Kliushnikov S.A., Nikol'skaia N.N., Miklina N.I. Molecular-genetic testing in diagnosis of sporadic cases of Huntington's disease. Zhurnal nevrologii i psihiatrii imeni S.S. Korsakova 1998; 98(3): 19-22.

7. Reilmann R., Leavitt B., Ross C. Diagnostic criteria for Huntington's disease based on natural history. Mov Disord 2014; 29(11): 1335-1341, https://doi.org/10.1002/mds.26011.

8. Bates G., Dorsey R., Gusella J., Hayden M., Kay C., Leavitt B., Nance M., Ross C.A., Scahill R.I., Wetzel R., Wild E.J., Tabrizi S.J. Huntington disease. Nat Rev Dis Primers 2015; 1: 15005, https://doi.org/10.1038/nrdp.2015.5.

9. Ross C., Aylward E., Wild E., Langbehn D., Long J., Warner J., Scahill R.I., Leavitt B.R., Stout J.C., Paulsen J.S., Reilmann R., Unschuld P.G., Wexler A., Margolis R.L., Tabrizi S.J. Huntington disease: natural history, biomarkers and prospects for therapeutics. Nat Rev Neurol 2014; 10(4): 204216, https://doi.org/10.1038/nrneurol.2014.24.

10. Ghosh R., Tabrizi S.J. Clinical features of Huntington's disease. Adv Exp Med Biol 2018; 1049: 1-28, https://doi. org/10.1007/978-3-319-71779-1_1.

11. van Wijngaarden P., Hadoux X., Alwan M., Keel S., Dirani M. Emerging ocular biomarkers of Alzheimer disease. Clin Experiment Ophthalmol 2016; 45(1): 54-61, https://doi. org/10.1111/ceo.12872.

12. Kersten H., Roxburgh R., Danesh-Meyer H. Ophthalmic manifestations of inherited neurodegenerative disorders. Nat Rev Neurol 2014; 10(6): 349-362, https://doi.org/10.1038/ nrneurol.2014.79.

13. Heidary G. Neuro-ophthalmic manifestations of pediatric neurodegenerative disease. J Neuroophthalmol 2017; 37: S4-S13, https://doi.org/10.1097/wno.0000000000000549.

14. Svetozarskiy S.N., Kopishinskaya S.V., Gustov A.V., Radyuk M.A., Antonova V.A., Smetankin I.G. Ophthalmic manifestations of Huntington's disease. Vestnik oftal'mologii 2015; 131(5): 82-86, https://doi.org/10.17116/ oftalma2015131582-86.

15. Kersten H., Danesh-Meyer H., Kilfoyle D., Roxburgh R. Optical coherence tomography findings in Huntington's disease: a potential biomarker of disease progression. J Neurol 2015; 262(11): 2457-2465, https://doi.org/10.1007/s00415-015-7869-2.

16. Andrade C., Beato J., Monteiro A., Costa A., Penas S., Guimarães J., Reis F., Garrett C. Spectral-domain optical coherence tomography as a potential biomarker in Huntington's disease. Mov Disord 2016; 31(3): 377-383, https://doi.org/10.1002/mds.26486.

17. Svetozarskiy S.N., Kopishinskaya S.V. Retinal optical coherence tomography in neurodegenerative diseases (review). Sovremennye tehnologii v medicine 2015; 7(1): 116123, https://doi.org/10.17691/stm2015.7.1.14.

18. Batcha A.H., Greferath U., Jobling A.I., Vessey K.A., Ward M.M., Nithianantharajah J., Hannan A.J., Kalloniatis M., Fletcher E.L. Retinal dysfunction, photoreceptor protein dysregulation and neuronal remodelling in the R6/1 mouse model of Huntington's disease. Neurobiol Dis 2012; 45(3): 887-896, https://doi.org/10.1016/j.nbd.2011.12.004.

19. O'Donnell B., Wilt M., Hake A., Stout J., Kirkwood S., Foroud T. Visual function in Huntington's disease patients and presymptomatic gene carriers. Mov Disord 2003; 18(9): 10271034, https://doi.org/10.1002/mds.10491.
20. O'Donnell B.F., Blekher T.M., Weaver M., White K.M., Marshall J., Beristain X., Stout J.C., Gray J., Wojcieszek J.M., Foroud T.M. Visual perception in prediagnostic and early stage Huntington's disease. J Int Neuropsychol Soc 2008; 14(03): 446-453, https://doi.org/10.1017/s1355617708080405.

21. Polevaya S.A., Parin S.B., Stromkova E.G. Psikhofizicheskoe kartirovanie funktsional'nykh sostoyaniy cheloveka. $\mathrm{V}$ kn.: Eksperimental'naya psikhologiya $v$ Rossii: traditsii $i$ perspektivy [Psychophysical mapping of human functional states. In: Experimental psychology in Russia: traditions and perspectives]. Pod red. Barabanshchikova V.A. [Barabanshchikov V.A. (editor)]. Moscow: Izd-vo "Institut psikhologii RAN"; 2010; p. 534-538.

22. Polevaya S., Parin S., Eremin E., Bulanov N., Chernova M., Parina I., Chikov M., Chernigovskaya T. Eventrelated telemetry (ERT) technology for study of cognitive functions. Int J Psychophysiol 2016; 108; 87-88, https://doi. org/10.1016/j.ijpsycho.2016.07.274.

23. Polevaya S.A., Parin S.B., Eremin E.V., Bulanov N.A., Chernova M.A. Razrabotka tekhnologii sobytiyno-svyazannoy telemetrii dlya issledovaniya kognitivnykh funktsiy. $\mathrm{V} \mathrm{kn}$.: XVIII Mezhdunarodnaya nauchno-tekhnicheskaya konferentsiya "Neyroinformatika-2016". Chast' 1 [Development of technology of event-related telemetry for the study of cognitive functions. In: XVIII International scientific and technical conference "Neuroinformatics-2016"]. Moscow: NIYaU MIFI; 2016; p. 34-44.

24. Parin S.B., Vetyugov V.V., Bakhchina A.V., Polevaya S.A. The role of the endogenous opioid system in the control of heart rate variability under cognitive loads of various levels. Sovremennye tehnologii v medicine 2014; 6(4): 116-126.

25. Ramamurthy M., Lakshminarayanan V. Human vision and perception. In: Handbook of advanced lighting technology. Springer International Publishing; 2015; p. 1-23, https://doi. org/10.1007/978-3-319-00295-8_46-1.

26. Bach $M$. The Freiburg Visual Acuity Test-variability unchanged by post-hoc re-analysis. Graefes Arch Clin Exp Ophthalmol 2007; 245(7): 965-971, https://doi.org/10.1007/ s00417-006-0474-4.

27. Neargarder S., Stone E., Cronin-Golomb A., Oross S. The impact of acuity on performance of four clinical measures of contrast sensitivity in Alzheimer's disease. The $J$ Gerontol B Psychol Sci Soc Sci 2003; 58(1): P54-P62, https://doi. org/10.1093/geronb/58.1.p54.

28. Pentland A. Maximum likelihood estimation: the best PEST. Percept Psychophys 1980; 28(4): 377-379, https://doi. org/10.3758/bf03204398.

29. Takeda S., Tajime K., Taniguchi T. The Takeda Three Colors Combination Test: a screening test for detection of very mild Alzheimer's disease. The Scientific World Journal 2014; 2014: 907316, https://doi.org/10.1155/2014/907316.

30. Bohnen N.I., Haugen J., Ridder A., Kotagal V., Albin R.L., Frey K.A., Müller M.L.T.M. Color discrimination errors associate with axial motor impairments in Parkinson's disease. Mov Disord Clin Pract 2017; 4(6): 864-869, https:// doi.org/10.1002/mdc3.12527.

31. Pelak V.S., Hills W. Vision in Alzheimer's disease: a focus on the anterior afferent pathway. Neurodegener Dis Manag 2018; 8(1): 49-67, https://doi.org/10.2217/nmt-2017-0030.

32. Risacher S.L., WuDunn D., Pepin S.M., MaGee T.R., McDonald B.C., Flashman L.A., Wishart H.A., Pixley H.S., Rabin L.A., Paré N., Englert J.J., Schwartz E., Curtain J.R., West J.D., O'Neill D.P., Santulli R.B., Newman R.W., Saykin A.J. Visual contrast sensitivity in Alzheimer's disease, 
mild cognitive impairment, and older adults with cognitive complaints. Neurobiol Aging 2013; 34(4): 1133-1144, https:// doi.org/10.1016/j.neurobiolaging.2012.08.007.

33. Polo V., Rodrigo M.J., Garcia-Martin E., Otin S., Larrosa J.M., Fuertes M.I., Bambo M.P., Pablo L.E., Satue M. Visual dysfunction and its correlation with retinal changes in patients with Alzheimer's disease. Eye 2017; 31(7): 10341041, https://doi.org/10.1038/eye.2017.23.

34. Nolan J.M., Loskutova E., Howard A.N., Moran R., Mulcahy R., Stack J., Bolger M., Dennison J., Akuffo K.O., Owens N., Thurnham D.I., Beatty S. Macular pigment, visual function, and macular disease among subjects with Alzheimer's disease: an exploratory study. J Alzheimers Dis 2014; 42(4): 1191-1202, https://doi.org/10.3233/jad-140507.

35. Ridder A., Müller M., Kotagal V., Frey K., Albin R., Bohnen N. Impaired contrast sensitivity is associated with more severe cognitive impairment in Parkinson disease. Parkinsonism Relat Disord 2017; 34: 15-19, https://doi. org/10.1016/j.parkreldis.2016.10.006.

36. Ming W., Palidis D.J., Spering M., McKeown M.J. Visual contrast sensitivity in early-stage Parkinson's disease. Invest Ophthalmol Vis Sci 2016; 57(13): 5696-5704, https://doi. org/10.1167/iovs.16-20025.

37. Artal P., Navarro R. Monochromatic modulation transfer function of the human eye for different pupil diameters: an analytical expression. J Opt Soc Am A Opt Image Sci Vis 1994; 11(1): 246, https://doi.org/10.1364/josaa.11.000246.
38. Clifford C.W.G. Visual perception: knowing what to expect. Curr Biol 2012; 22(7): R223-R225, https://doi. org/10.1016/j.cub.2012.02.019.

39. Massey T.H., Jones L. The central role of DNA damage and repair in CAG repeat diseases. Dis Model Mech 2018; 11(1): dmm031930, https://doi.org/10.1242/dmm.031930.

40. Kopshynskaya S.V., Antonova V.A., Gustov A.V. Huntington's disease. Zhurnal nevrologii $i$ psihiatrii imeni S.S. Korsakova 2014; 114(1): 74-79.

41. La Morgia C., Di Vito L., Carelli V., Carbonelli M. Patterns of retinal ganglion cell damage in neurodegenerative disorders: parvocellular vs magnocellular degeneration in optical coherence tomography studies. Front Neurol 2017; 8: 710, https://doi.org/10.3389/fneur.2017.00710.

42. Baake V., Reijntjes R., Dumas E., Thompson J., Roos R. Cognitive decline in Huntington's disease expansion gene carriers. Cortex 2017; 95: 51-62, https://doi. org/10.1016/j.cortex.2017.07.017.

43. Fedotchev A.I., Parin S.B., Polevaya S.A., Velikova S.D. Brain-computer interface and neurofeedback technologies: current state, problems and clinical prospects (review). Sovremennye tehnologii $v$ medicine 2017; 9(1): 175-184, https://doi.org/10.17691/stm2017.9.1.22.

44. Petukhov A., Polevaya S. Modeling of communicative individual interactions through the theory of information images. Current Psychology 2016; 36(3): 428-433, https://doi. org/10.1007/s12144-016-9431-5. 